MATEC Web of Conferences 39, 03004 (2016)

DOI: $10.1051 /$ matecconf/20163903004

(C) Owned by the authors, published by EDP Sciences, 2016

\title{
Measurement and Analysis of the Diffusible Hydrogen in Underwater Wet Welding Joint
}

\author{
Kong Xiangfeng ${ }^{1,2}$, Li Chunhu' ${ }^{1}$, Zou Yan², Zhang Jing ${ }^{2, a}$, Hu Yunchuan² and Wang Jia ${ }^{1}$ \\ ${ }^{1}$ College of Chemistry and Chemical Engineering, Ocean University of China, NO.238, Songling Road, Qingdao, Shandong, China; \\ ${ }^{2}$ Institute of Oceanographic Instrumentation, Shandong Academy of Sciences, NO.28, Zhejiang Road, Qingdao, Shandong, China;
}

\begin{abstract}
The diffusible hydrogen in steel weldments is one of the main reasons that led to hydrogen assisted cracking. In this paper, the results of literatures survey and preliminary tests of the diffusible hydrogen in underwater wet welding joint were presented. A fluid-discharge method of for measuring the diffusible hydrogen in weldment was introduced in detail. Two kinds of underwater welding electrode diffusible hydrogen are $26.5 \mathrm{~mL} / 100 \mathrm{~g}$ and 35.5 $\mathrm{mL} / 100 \mathrm{~g}$ by fluid-discharge method, which are high levels. The diffusible hydrogen of underwater welding is higher than atmospheric welding, and the result is closely related to welding material. The best way to control the diffusible hydrogen is adjusting welding material and improving fluidity of slag.
\end{abstract}

\section{Introduction}

Underwater wet welding technique is part of the methods used in underwater construction and repair. The increasing uses of offshore structures such as platforms, storage tanks, and pipelines have created more demand for development of underwater welding techniques. However, wet welding process gives low weld quality since it is made in worst welding environment.[1] In special cases, to obtain high quality underwater welds and to develop more reliable processes, various welding consumables may be welded with mild steel, and the performance of welding joint must be investigated. In underwater welding, cooling conditions and diffusible hydrogen amount in weld metal differ from that welding in the air. The high quenching rate caused by the water environment and substantial quantities of hydrogen in water can cause many severe problems in welds such as severe porosity and hydrogen induced cracking.[2] The diffusible hydrogen, susceptible microstructure and tensile stress are the causative factors in the hydrogen cracking of steel welds. Since it is difficult to control the cooling conditions and tensile stress in underwater wet welding, the best way to reduce the risk of cracking is reducing the diffusion of hydrogen content.

There is no direct way of measuring the diffusible hydrogen in a production weld. But there are several methods for the measurement of releasing diffusible hydrogen from weldment, including the most common methods glycerin method, mercury method, gas chromatography method and hot extraction. Among these methods, the glycerin method is the oldest and the most commonly used method. Hydrogen is partially soluble and adsorbing in the high viscosity glycerin, so the measurements were underestimated and widely scattered. Therefore, the glycerin method is not appropriate for the measurement of lower levels of hydrogen. However, glycerin method is still in use by many scientists, on account of simple devices and easy operation compared to other methods.

A number of reports on testing the diffusible hydrogen in underwater wet welding joint are available It was noted that the measured diffusible hydrogen contents of underwater wet welds are more dependent on the type of electrode covering than on the weld metal oxygen content[3]. Welds deposited by rutile electrodes presented approximately $90 \mathrm{~mL} / 100 \mathrm{~g}$ of diffusible hydrogen while oxidizing electrodes produced welds with diffusible hydrogen contents varying from 40 to $50 \mathrm{~mL} / 100 \mathrm{~g}$. Medeiros and Liu [4] contend that diffusible hydrogen content was strongly dependent on the solubility of water in the slag systems, and it increased monotonically with increasing slag hydrogen content. In this investigation, the slag/metal interface was identified as responsible for controlling the weld metal hydrogen pickup. Świerczyńska has tried to minimize the amount of diffusible hydrogen by changing the welding parameters[5]. Recently, it was reported that the main sources of diffusible hydrogen were organics or crystal water in the electrode covering and the waterproof layer. By comparison, water around the arc contributed

\footnotetext{
a Corresponding author: kxf_1985@163.com
} 
little to the crease of diffusible hydrogen content[6]. With the investigation, the results tend to be inconsistent.

The studies of underwater wet weld began in Institute of Oceanographic Instrumentation from 2008, and electrodes were researched and developed independently. The characteristics of underwater weldment have been reported in many articles[7-9], including mechanical property, chemical composition, metallographic structure and corrosion behavior. In the present study, diffusible hydrogen was determined using the improved glycerin method.

\section{Experimental materials approach}

\subsection{Experimental materials}

The E40 steel which conforms to the CCS (China Classification Society) specification was used as base material in this study. Table $\mathbf{1}$ indicates the mechanical property and chemical composition of E40 steel. The samples with the thickness of $12 \mathrm{~mm}$ were cut into $25 \mathrm{~mm} \times 80 \mathrm{~mm}$ and $25 \mathrm{~mm} \times 50 \mathrm{~mm}$ in size. They were dried at $650{ }^{\circ} \mathrm{C}$ for 1 hour to remove any remain hydrogen as much as possible. The surfaces were cleaned up after samples cooled. Then the $80 \mathrm{~mm}$ samples were numbered and weighed before welding (initial weight $\mathrm{m}_{1}$ ). The $50 \mathrm{~mm}$ samples were used for run-on and run-off tabs.

Table 1 Mechanical property and chemical composition

\begin{tabular}{|c|c|c|c|}
\hline & Steel & & E40 \\
\hline \multirow{3}{*}{$\begin{array}{c}\text { Mechanical } \\
\text { property }\end{array}$} & Yield point & $\sigma \mathrm{s}(\mathrm{MPa})$ & $\geqq 390$ \\
\hline & $\begin{array}{l}\text { Tensile } \\
\text { Strength }\end{array}$ & $\sigma b(\mathrm{MPa})$ & $510-660$ \\
\hline & Elongation & $\sigma \%$ & $\geqq 20$ \\
\hline \multirow{5}{*}{$\begin{array}{l}\text { Chemical } \\
\text { composition }\end{array}$} & \multicolumn{2}{|c|}{$\mathbf{C}$} & $\leqq 0.18$ \\
\hline & \multicolumn{2}{|c|}{ Mn } & $\geqq 0.9-1.6$ \\
\hline & \multicolumn{2}{|c|}{$\mathbf{S i}$} & $\leqq 0.5$ \\
\hline & \multicolumn{2}{|c|}{$\mathbf{S}$} & $\leqq 0.035$ \\
\hline & \multicolumn{2}{|c|}{$\mathbf{P}$} & $\leqq 0.035$ \\
\hline
\end{tabular}

The electrodes 359S and 524A which independent researched and developed by Institute of Oceanographic Instrumentation were used in this study. The same materials were also used to make air welds so that comparisons could be made between underwater and air welds.

\subsection{Experimental procedure}

The prepared samples and tab plate were contacted with work clamp and immerged into the water tank. Welding current was set at $160 \mathrm{~A}$ and welding voltage was set at $28 \mathrm{~V}$. The single-pass welding was operated by a welder in the water tank $1 \mathrm{~m}$ under water. Short-arc welding should be adopted as far as possible, and weld procedure should be complete without arc extinguishing. Take the welded sample out water, and then get rid of welding slag and other impurities quickly (Figure1). After knocking off run-on and run-off tabs, remove water and oil from sample with the alcohol, and dry the sample with cool wind afterwards.

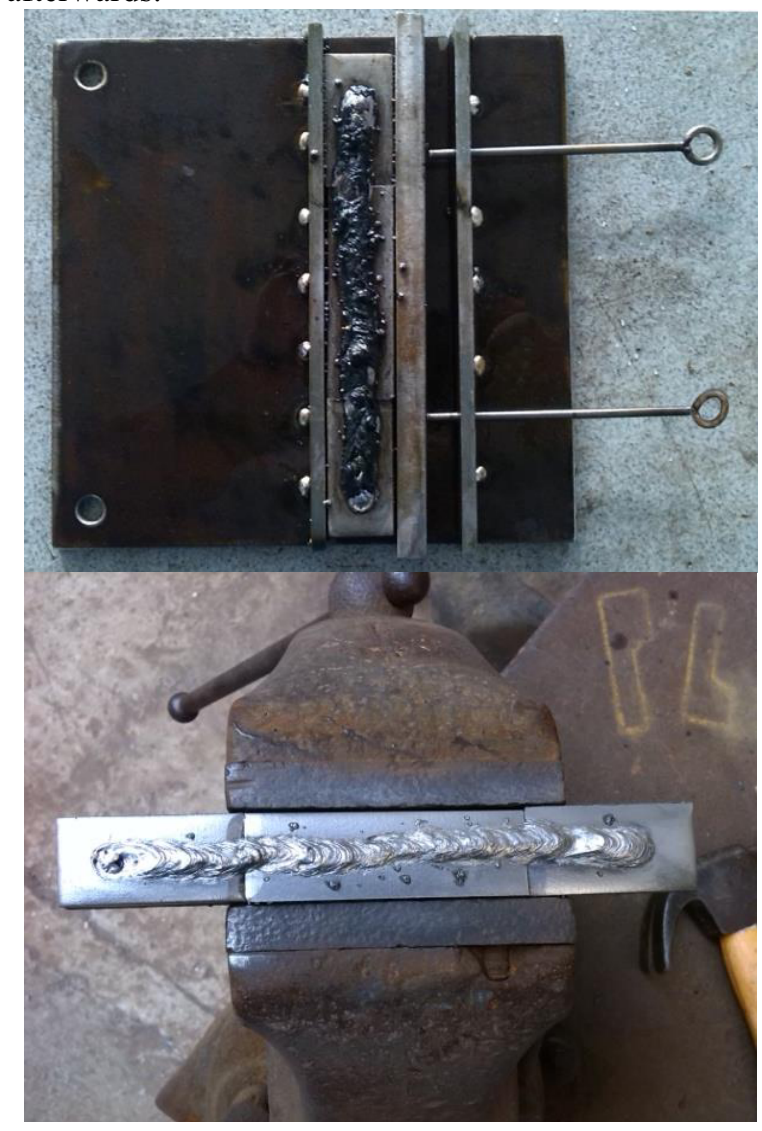

Figure 1.The jig and weldment

At last, put the sample into a vessel of collecting gas as showed in Figure 2 and cover it. The vessel filled with glycerin were stored in $25{ }^{\circ} \mathrm{C}$ incubator ahead for 24 hours. The process from welded to put it into vessel should be completed in 60 seconds. By controlling the plug valve 2 and 5 , release excess gas and adjust gauge glass 6 fluid level, make sure that there was no gas in vessel. Collection of gas shall be performed by immersing the sample in glycerin maintained at $45^{\circ} \mathrm{C}$ for 48 hours. And some of glycerin was discharged to gauge glass 6 , because the diffusible hydrogen occupied a fraction of the site. The volume of diffusible hydrogen collected at the top of the gauge glass 3 and the fluid level of gauge glass 6 was read and recorded (volume V). In this way, the volume of gas and liquid removed can be measured, and the error caused by soluble and adsorbing was eliminated. 


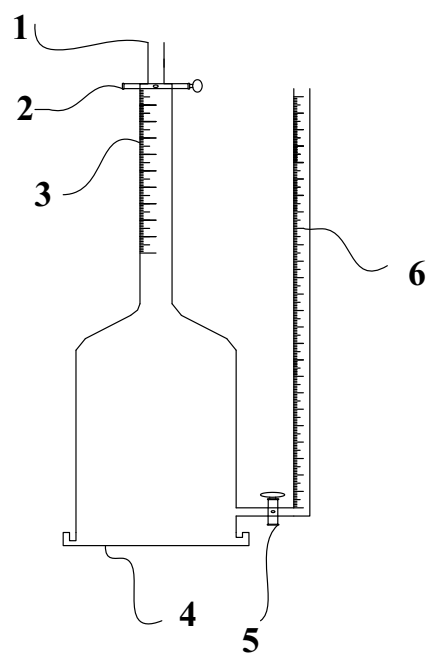

Figure 2. Illustrate of diffusible hydrogen collector

equipment setup.

Then the sample that was removed from glassware was rinsed in water, dried and weighed (final weight $\mathrm{m}_{2}$ ). The weight of the deposited weld metal was determined by the difference between initial and final weight. For each sample, the volume of diffusible hydrogen collected per $100 \mathrm{~g}$ of deposited weld metal was calculated.

In contrast, atmospheric weld parameters were set to the same value with underwater weld. After the completion of the atmospheric weld, the sample was rapidly cooled by immersion in $25{ }^{\circ} \mathrm{C}$ water for 10 seconds. And then the processing method of sample was same to underwater weldment.

\section{Analyses and interpretation}

The amount of diffusible hydrogen was calculated per $100 \mathrm{~g}$ of weld deposit by the next Formula 1.

$$
V_{H}=\frac{V}{m_{2}-m_{1}} \times 100(m L / 100 g)
$$
3.

The end results were shown in Table 2 and Figure

Table 2: Hydrogen diffusion quantity

\begin{tabular}{cccc}
\hline \multicolumn{2}{c}{ Type of Welding Electrode } & $359 \mathrm{~S}$ & $524 \mathrm{~A}$ \\
\hline $\begin{array}{c}\text { Underwater } \\
\text { Weld }\end{array}$ & $\begin{array}{c}\text { Gas } \\
\text { Volume } \\
\text { Liquid } \\
\text { Volume } \\
\text { Gas }\end{array}$ & 15.7 & 24 \\
$\begin{array}{c}\text { Atmospheric } \\
\text { Weld }\end{array}$ & $\begin{array}{c}\text { volume } \\
\text { Liquid } \\
\text { Volume }\end{array}$ & 11.2 & 16.5 \\
\hline
\end{tabular}

Figure 4. Hydrogen diffusion quantity of gas collection vs. fluid-discharge

Based on experimental data, a straight-line formula of gas collection vs. fluid-discharge is also obtained as shown in Figure 4 and Formula 4.

$$
\mathrm{H}_{\text {gas }}=0.622 \mathrm{H}_{\text {fluid }}+0.5024
$$

According to this formula, the results were consistent with the data reported previously. Chen et al.[11] confirmed the reliability of measurement result in the report. Fluid-discharge method was easy and reliable way to measure the diffusible hydrogen.

\subsection{Diffusible hydrogen of underwater weldment}


As shown in Table 2 and Figure 3, the diffusible hydrogen of underwater welding is higher than atmospheric welding. Two kinds of welding electrode diffusible hydrogen are $26.5 \mathrm{~mL} / 100 \mathrm{~g}$ and 35.5 $m L / 100 g$, which are high levels. In the quenching effect of seawater, there are risks of cracking.[12] Although the mechanical properties could meet the requirement, the critical underwater welding parts must be quality inspected, especially the long-term service offshore structures.

To be inconsistent with report, the gap between the two kinds of welding circumstances is wider than it has ever been reported by Cheng [6], but it is smaller than Nakpradit's[13] report. The content of diffusible hydrogen is closely related to welding material, welding parameters, welding circumstances, and so on. The water depth or slag/metal interface could affect the diffusible hydrogen in underwater weldment.[4,14] The foremost of these is controlling the diffusible hydrogen to prevent hydrogen cracking. But the underwater circumstance hinders these measures for removing diffusible hydrogen, including post-weld heat treatment. The best way is adjusting welding material and improving fluidity of slag.[15]

\section{Conclusions}

(1) A fluid-discharge method of for measuring the diffusible hydrogen in underwater wet welding joint has been applied. Fluid-discharge method was easy and reliable way to measure the diffusible hydrogen. This method provides accurate results in comparison with mercury. On the other hand, it provides data of glycerine method in the meantime.

(2) The diffusible hydrogen of underwater welding is higher than atmospheric welding. Two kinds of welding electrode diffusible hydrogen are $26.5 \mathrm{~mL} / 100 \mathrm{~g}$ and $35.5 \mathrm{~mL} / 100 \mathrm{~g}$, which are high levels. The result is closely related to welding material.

\section{Acknowledgements}

The authors acknowledge and appreciate the financial support by National Natural Science Foundation of China (No.51209129).

\section{References}

1. Fydrych D, Łabanowski J, Rogalski G. Weldability of high strength steels in wet welding conditions[J]. Polish Maritime Research, 2013, 20(2): 67-73.

2. Kralj Slobodan, Garašić Ivica, Kožuh Zoran. Diffusible hydrogen in underwater wet welding[M]. Welding in the World, 2008, 52: 687-692
3. Pope A M, Liu S. Hydrogen content of underwater wet welds deposited by rutile and oxidizing electrodes[R]. American Society of Mechanical Engineers, New York, NY (United States), 1996.

4. De Medeiros R C, Liu S. A predictive electrochemical model for weld metal hydrogen pickup in underwater wet welds[J]. Journal of offshore mechanics and Arctic Engineering, 1998, 120(4): 243-248.

5. Świerczyńska A, Fydrych D, Łabanowski J. The effect of welding conditions on diffusible hydrogen content in deposited metal[C]//Solid State Phenomena. 2012, 183: 193-200.

6. Cheng Fangjie, Hu Shenghui, Gao Wenbin, et al. Diffusible hydrogen content and microstructure characteristic in the joint by underwater shielded metal arc welding[J]. Transactions of the China Welding Institution, 2014, 35(9): 45-48

7. Guo N, Yang Z, Wang M, et al. Microstructure and Mechanical Properties of an Underwater Wet Welded Dissimilar Ferritic/Austenitic Steel Joint[J]. Strength of Materials, 2015, 47(1): 12-18.

8. Jia $\mathrm{C}$, Zhang $\mathrm{T}$, Maksimov $\mathrm{S} \mathrm{Y}$, et al. Spectroscopic analysis of the arc plasma of underwater wet flux-cored arc welding[J]. Journal of Materials Processing Technology, 2013, 213(8): 1370-1377.

9. Han Yanfei, Guo Ning, Wang Fang, et al.Effects of process parameters on the depth-to-width ratio of flux-cored wire underwater wet welding $[\mathrm{J}]$. CHINA WELDING, 2013, 22(1):35-40

10. Kotecki D J. Hydrogen measurement and standardization[C]. Melbourne: Welding Technology Institute of Australia, 1996: 87-102.

11. Chen Banggu, Zhang Wenyue, Du Yuze, et al. Research of measuring diffusible hydrogen in welding joint with fluid-discharge method[J]. Transactions of the China Welding Institution. 1984, 5(4): 188-194.

12. Nakpradit T, Poopat B. Investigation of Diffusible Hydrogen Content and Microstructure Examination of Underwater Welding[J]. KMUTNB: International Journal of Applied Science and Technology, 2010, 3(3): 45-51. 
13. da Silva W C D, Ribeiro L F, Bracarense A Q, et al. Effect of the Hydrostatic Pressure in the Diffusible Hydrogen at the Underwater Wet Welding[C]//ASME $2012 \quad 31$ st International Conference on Ocean, Offshore and Arctic Engineering. American Society of Mechanical Engineers, 2012: 1-8.

14. Silva W C D, Bracarense A Q, Pessoa E C P. Effect of water depth on diffusible hydrogen on wet welds[J]. Soldagem \& Inspeção, 2012, 17(4): 298-305.

15. Du Plessis J, Du Toit M. Reducing diffusible hydrogen contents of shielded metal arc welds through addition of flux-oxidizing ingredients[J]. Journal of Materials Engineering and Performance, 2008, 17(1): 50-56. 